\title{
Postpartal immunometabolic gene network expression and function in blood neutrophils are altered in response to prepartal energy intake and postpartal intramammary inflammatory challenge ${ }^{1}$
}

\author{
K. M. Moyes, ${ }^{2}$ D. E. Graugnard, $† \ddagger$ M. J. Khan, $\nmid \ddagger^{3}$ M. Mukesh, $\S$ and J. J. Loor $† \ddagger^{2}$ \\ ${ }^{*}$ Department of Animal and Avian Sciences, University of Maryland, College Park 20742 \\ †Mammalian NutriPhysioGenomics, and \\ $\ddagger$ Department of Animal Sciences and Division of Nutritional Sciences, University of Illinois, Urbana 61801 \\ §National Bureau of Animal Genetic Resources, P.B. 129, GT Road Bye Pass, Karnal-132001, Haryana, India
}

\section{ABSTRACT}

The effect of over-feeding energy prepartum on blood polymorphonuclear neutrophil (PMN) response remains unclear. Cows fed controlled (CON; 1.34 Mcal/ $\mathrm{kg}$ of dry matter) or excess energy (OVE; $1.62 \mathrm{Mcal} /$ $\mathrm{kg}$ dry matter) during the dry period ( $\sim 45 \mathrm{~d}$ before expected calving date) received an intramammary (IM) challenge with Escherichia coli lipopolysaccharide (LPS) during the postpartal period to determine the effects of IM LPS and prepartal diet on the expression of key genes associated with immunometabolic response in blood PMN. Feed intake and daily milk yield were recorded throughout the study period. At 7 $\mathrm{d}$ in milk (DIM), all cows received LPS $(200 \mu \mathrm{g})$ into 1 rear mammary quarter. Blood PMN were isolated at 7,14 , and 30 DIM, as well as before $(0 \mathrm{~h})$ and after $(12$ h) IM LPS challenge for gene expression analysis using quantitative real time PCR. Phagocytosis capabilities in vitro were assessed at 7,14 , and 30 DIM. Data were analyzed using the MIXED procedure of SAS with repeated measures. No differences in feed intake and milk yield were observed between OVE- and CON-fed cows. As expected, IM LPS challenge altered the expression of genes associated with the immune response (e.g., 1.9- and 1.8-fold for SELL and TLR2, respectively), metabolism (e.g., 1.8- and -1.8-fold for $L D H A$ and $S L C 2 A 1$, respectively), and transcription (e.g., 1.1- and 1.7-fold for NCOR1 and PPARD, respectively). At 12 $\mathrm{h}$ postchallenge, an upregulation of TLR2 (1.8-fold), HIF1A (1.9-fold), and NFKB1 (1.5-fold) was observed for OVE rather than CON. At 7 DIM, S100A9 tended (2.2-fold) to be upregulated for OVE rather than CON.

\footnotetext{
Received August 28, 2013.

Accepted December 23, 2013.

${ }^{1}$ Supported in part by National Research Initiative (NRI) competitive grant 2007-35204-17758.

${ }^{2}$ Corresponding authors: kmoyes@umd.edu and jloor@illinois.edu

${ }^{3}$ Current address: Department of Biosciences, COMSATS Institute of Information Technology, Islamabad, Pakistan.
}

At 14 DIM, OVE resulted in lower PMN phagocytosis and an upregulation of NCOR2 (1.6-fold) and RXRA (1.9-fold) compared with CON-fed cows. At 30 DIM, an upregulation of MPO (3.5-fold) and PLA2G4A (1.5fold) and a tendency for $R X R A$ (1.7-fold) was observed for OVE- rather than CON-fed cows. Our results suggest that IM LPS challenge altered gene expression associated with metabolism in PMN and that OVE impaired PMN phagocytosis and increased the expression of immunometabolic genes after IM LPS challenge and during the postpartal period. The current study provides new linkages among prepartal feed energy intake, metabolism, and immune response of blood PMN and risk of disease during early lactation.

Key words: intramammary inflammatory challenge, blood neutrophil immune response, prepartal feed energy intake

\section{INTRODUCTION}

Mastitis, an inflammation of the mammary gland, is the most costly disease in the dairy industry (exceeding $\$ 2$ billion annually) and occurs most frequently during the periparturient period (Bar et al., 2008). Mastitis is usually associated with the presence of an invading microorganism, such as Escherichia coli. Lipopolysaccharide endotoxin is released from the cell wall of $E$. coli, inducing an inflammatory response (Hoeben et al., 2000). Administration of LPS reflects many aspects of the host inflammatory response to $E$. coli mastitis and has been proposed as a better model to study host response to $E$. coli due to the relatively greater control of dose when compared with inoculation with E. coli (Raetz and Whitfield, 2002). During mastitis, circulating polymorphonuclear neutrophils (PMN) become the predominant cell type in the mammary gland, accounting for approximately $95 \%$ of somatic cell population, and are therefore of critical importance for resolution of mastitis (Burvenich et al., 2004). Hence, impairment of PMN function during the transition period exacerbates 
susceptibility to mastitis (Paape et al., 2003). One main functions of PMN is to phagocytose (i.e., engulf, and kill invading organisms; Paape et al., 2002). During E. coli mastitis, PMN also secrete proinflammatory cytokines [e.g., tumor necrosis factor- $\alpha$ (TNF- $\alpha)$, IL-8, and IL-1 $\beta$ ] via LPS activation of both toll-like receptor (TLR) 4 and TLR-2 and the NF-kB proinflammatory signaling cascade that encompasses the activation of myeloid differentiation primary response gene 8, TNF receptor-associated family-6, IL-1 receptor-associated kinase 1, and the I $\kappa$ B kinase complex (Wesche et al., 1997).

We have previously shown that metabolic status alters the expression of genes associated with inflammation in bovine blood PMN (Moyes et al., 2010). When compared with cows in positive energy balance, cows subjected to dietary-induced negative energy balance in mid lactation had a downregulation of key genes in bovine blood PMN that are involved in the inflammatory response (i.e., IRAK1 and TNF; Moyes et al., 2010). However, the metabolic changes that occur during early lactation and their linkages to impaired PMN function during inflammation are only partly known (Ingvartsen and Moyes, 2013). The metabolic fates of energetic fuels in bovine PMN during inflammation have not been characterized. Glucose is the primary fuel used by leukocytes (e.g., PMN) and serve as an essential substrate for optimal PMN function (Pithon-Curi et al., 2004). Yet, because glucose is in high demand to support milk synthesis in early lactation, supply to PMN may be compromised. Characterizing changes in key genes involved in glucose metabolism [e.g., solute carrier family 2 (facilitated glucose transporter), member 1 (SLC2A1), glucose-6-phosphate dehydrogenase $(\boldsymbol{G 6 P D})$ and lactate dehydrogenase- $\alpha(\boldsymbol{L D H A})]$ in PMN during inflammation may lead to new strategies to improve PMN function and thereby control mastitis during early lactation.

Controlling energy intake during the dry period has been shown to optimize lipid metabolism, thereby preventing large changes in liver lipid and triacylglycerol accumulation postpartum in Holstein cows during early lactation (Janovick et al., 2011). Furthermore, large changes in calculated energy balance and plasma NEFA and BHBA were reduced (Dann et al., 2006; Janovick et al., 2011). We have recently observed that overfeeding energy prepartum results in marked alterations of adipose (Ji et al., 2012) and liver (Bionaz and Loor, 2012) tissue metabolic and immune gene networks. In addition, when compared with cows fed controlled energy (1.34 Mcal/kg of DM), cows over-fed energy (1.62 Mcal $/ \mathrm{kg}$ of DM) during the dry period had an altered acute phase response (i.e., an indicator of inflammatory response of liver) when evaluating blood biomarkers and hepatic gene expression [i.e., serum amyloid A1 and haptoglobin; Graugnard et al., 2013). Although data are scarce, bovine blood immune cell function is responsive to exogenous NEFA (Lacetera et al., 2004; Scalia et al., 2006), and recent in vitro data demonstrated that long-chain FA can alter the production of proinflammatory cytokines at least in part via the activation of peroxisome proliferator-activated receptors (PPAR) signaling (Perdomo et al., 2011). Thus, it is possible that prepartal overfeeding of energy, by inducing a greater and more sustained response in blood NEFA, could indirectly alter the expression of PPAR isotypes and their targets in the PMN.

The above observations raise the question of whether allowing ad libitum access to high-energy diets during the dry period affects gene networks in PMN and potentially helps to control or prevent mastitis during the early postpartal period. The specific objectives of the current study were to characterize the expression of inflammatory and metabolic-related genes in blood PMN after an intramammary (IM) challenge and how feeding controlled or excess energy during the dry period alters this response during the early postpartal period.

\section{MATERIALS AND METHODS}

\section{Animals and Diets}

All procedures were conducted under protocols approved by the University of Illinois Institutional Animal Care and Use Committee (Protocol \# 06145). Details of the animal experimental design have been published previously (Graugnard et al., 2013). Briefly, Holstein cows ( $\mathrm{n}=20$ per dietary treatment) entering their second or greater lactation were assigned randomly at dry off $(-45 \mathrm{~d}$ before the expected calving date) to a control diet (controlled energy, high fiber; CON; 1.34 Mcal/kg of diet DM) providing approximately $100 \%$ of calculated $\mathrm{NE}_{\mathrm{L}}$ requirements or a diet to provide at least $150 \%$ of calculated $\mathrm{NE}_{\mathrm{L}}$ requirements (overfed group; OVE; $1.62 \mathrm{Mcal} / \mathrm{kg}$ of $\mathrm{DM})$ during the entire 45-d dry period (NRC, 2001). After parturition, cows were moved to a tiestall barn, fed a common lactation $\operatorname{diet}\left(\mathrm{NE}_{\mathrm{L}}=1.69 \mathrm{Mcal} / \mathrm{kg}\right.$ of $\left.\mathrm{DM}\right)$, and milked twice daily (0400 and $1600 \mathrm{~h}$ ). Diets were fed as a TMR once daily (0600 h) using an individual gate feeding system (American Calan, Northwood, NH) during the dry period or in open individual mangers during lactation. Calculation of energy balance, sampling of blood, milk, feed ingredients, and TMR for composition analyses, and housing of cows pre- and postpartum is reported by Graugnard et al. (2013). Daily DMI was calculated and milk yield was recorded throughout the study period. 


\section{LPS Challenge}

Details of IM LPS challenge were reported previously (Graugnard et al., 2013). Briefly, at 7 DIM, 10 CON cows and 10 OVE cows received $200 \mu \mathrm{g}$ of E. coli LPS (strain 0111:B4, Sigma Aldrich, St. Louis, MO) dissolved in $20 \mathrm{~mL}$ of $0.09 \%$ sterile physiological saline (Hospira, Lake Forest, IL) into a rear quarter of the mammary gland. The infused quarter was thoroughly massaged.

\section{Neutrophil Isolation}

Samples of blood $(\sim 120 \mathrm{~mL})$ were collected at 7 (i.e., $0 \mathrm{~h}$ ), 14, and $30 \mathrm{DIM}$, as well as $12 \mathrm{~h}$ relative to LPS challenge via coccygeal venipuncture using Vacutainer tubes (Becton Dickinson Co., Franklin Lakes, NJ) containing acid citrate dextrose (ACD Solution A; Fisher Scientific, Pittsburgh, PA). Tubes were placed on ice and PMN were isolated as previously described (Graugnard et al., 2013). Isolated PMN were immediately homogenized in $2 \mathrm{~mL}$ of TRIzol reagent (Invitrogen, Carlsbad, CA) with $1 \mu \mathrm{L}$ of linear acrylamide (Ambion Inc., Austin, TX) using a hand-held tissue homogenizer. The suspension was then transferred equally into 2 RNA-free microcentrifuge tubes $(2 \mathrm{~mL}$; Fisher Scientific) and stored at $-80^{\circ} \mathrm{C}$ until further analysis.

\section{Phagocytosis}

Neutrophils were isolated from all cows selected for gene expression analysis at 7 (i.e., before LPS challenge), 14, and 30 DIM for in vitro phagocytosis capabilities. Phagocytosis of blood PMN was conducted as previously described (Graugnard et al., 2012). Briefly, phagocytosis was conducted in quadruplicate in $1 \mathrm{~mL}$ of RPMI 1640 medium following addition of a 1:10 ratio of Fluoresbrite latex Carboxy Yellow-Green 1.75$\mu \mathrm{m}$ Microspheres (2.5\%, \#17687; Polysciences Inc., Warrington, PA). Samples were then incubated for 2 $\mathrm{h}$ in $5 \% \mathrm{CO}_{2}, 95 \%$ humidity at $37^{\circ} \mathrm{C}$. After incubation, cells were rinsed twice with $1 \times$ PBS (via centrifugation at $1,000 \times g$ for $5 \mathrm{~min}$ at $4^{\circ} \mathrm{C}$ ), fixed with $150 \mu \mathrm{L}$ of $4 \%$ paraformaldehyde (P6148; Sigma Aldrich), and preserved at $4^{\circ} \mathrm{C}$ until reading using flow cytometry.

\section{Quantitative Reverse Transcription PCR}

A subset of CON- $(\mathrm{n}=8)$ and OVE-fed $(\mathrm{n}=5)$ cows were selected for gene expression profiling. The selected cows were those with a complete set of PMN RNA at each of the time points examined. Specific details of RNA isolation from PMN, primer design, evaluation, and quantitative real time PCR are presented in
Supplemental Materials (http://dx.doi.org/10.3168/ jds.2013-7433). The official gene symbol, gene name, and a short summary description of the most relevant biological functions of the genes evaluated are presented in Supplemental Table 1. Details of primer product sequencing results, primer sequence and amplicon size, and quantitative real time PCR performance are reported in Supplemental Tables 2, 3, and 4. The final data were normalized using the geometric mean of $G A P D H, R P S 9$, and $U X T$, which were previously verified as suitable internal control genes (ICG) in bovine tissues (Graugnard et al., 2013; Khan et al., 2013). The pairwise variation $(\mathrm{V} 2 / 3)$ of these ICG using geNorm (Vandesompele et al., 2002) was $<0.2$, hence, they were deemed suitable as ICG. Target genes were normalized with the geometric mean of the 3 ICG.

\section{Statistical Analysis}

Genes were normalized with ICG and $\log _{2}$ transformed before statistical analysis. Data were analyzed using the MIXED procedure of SAS (SAS Institute Inc., Cary, NC) with a random effect of cow. The data were analyzed separately relative to time by (1) 7,14 , and 30 DIM and (2) 0 (i.e., 7 DIM) and $12 \mathrm{~h}$ relative to intramammary IM LPS challenge. Class variables included cow, diet (OVE and CON), and time (i.e., 0 and $12 \mathrm{~h}$ relative to LPS challenge or 7, 14, and 30 DIM). The model included time, diet and their interaction. Relative expression values for tables and figures are presented as LSM and SEM. Separation of LSM for significant effects was accomplished using the Tukey's option within the MIXED procedure of SAS. Differences were declared as significant at $P \leq 0.05$. Trends toward significance are discussed at $P<0.10 . \log _{2}$-transformed data were back-transformed for presentation in tables and figures. The expression of IRS1, TLR4, F2RL1, and $I L 6$ were deemed undetectable because the median cycle threshold was $>30$. Fold-change is represented as the differences between OVE versus CON.

\section{RESULTS}

\section{Effect of IM LPS Challenge}

The effect of IM LPS challenge for CON and OVE cows at 7 DIM on blood PMN gene expression is reported in Table 1. Although overall significant interactions between prepartal diet and hour relative to IM LPS challenge were observed, no differences were observed for the expression of IL1B, ITGAM, NCOR1, RXRA, and SLC2A1 at 0 or $12 \mathrm{~h}$ between OVE- and CONfed cows. After IM LPS challenge, no genes associated with inflammation, metabolism, or transcription were 
Table 1. Quantitative real-time PCR gene expression of blood neutrophils isolated 0 and $12 \mathrm{~h}$ after intramammary challenge with lipopolysaccharides in dairy cows at 7 DIM fed either control ${ }^{1}(\mathrm{CON})$ or excess energy $(\mathrm{OVE})$ during the dry period

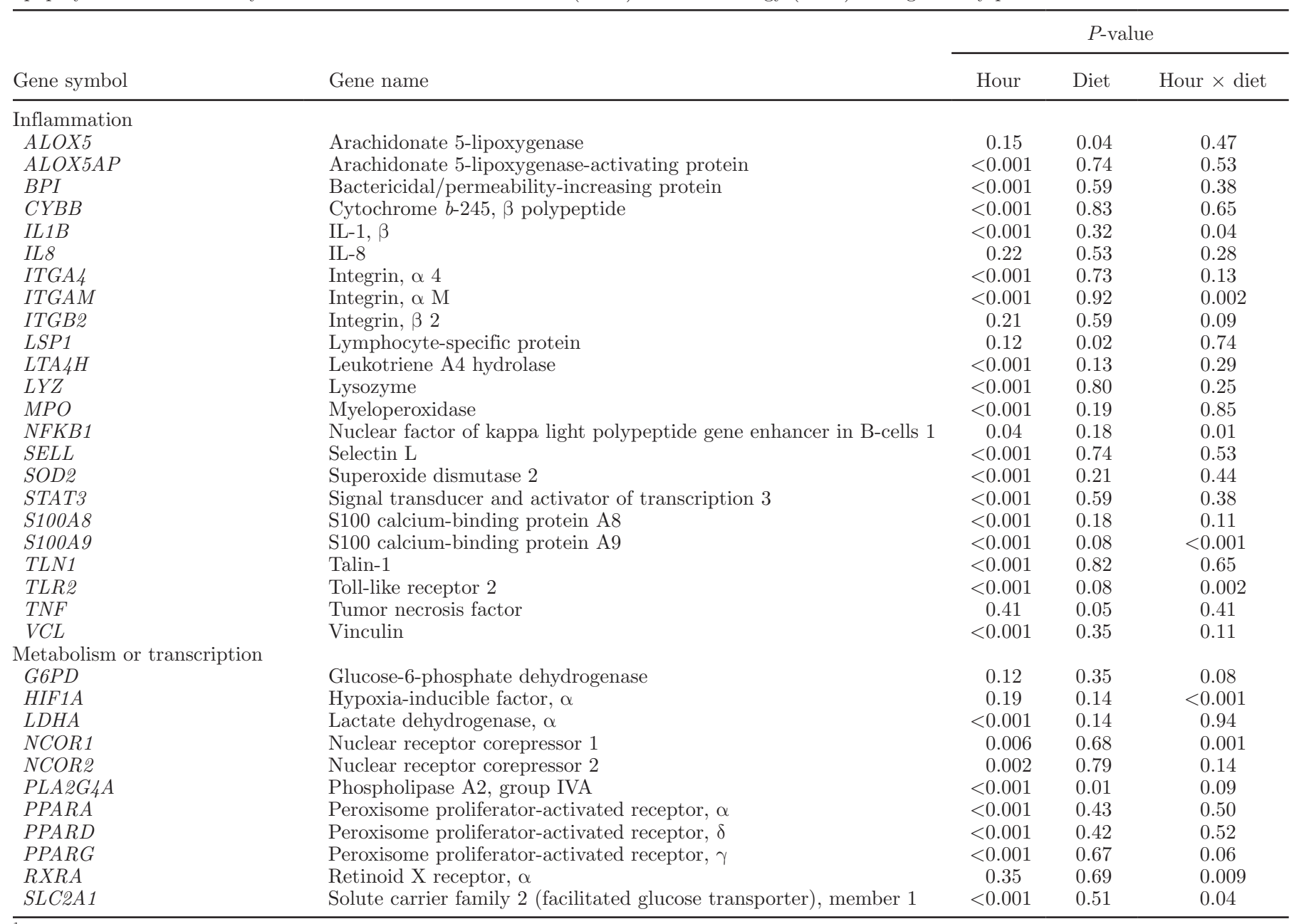

${ }^{1} \mathrm{CON}=1.34 \mathrm{Mcal} / \mathrm{kg}$ of $\mathrm{DM}, \mathrm{n}=8 ; \mathrm{OVE}=1.62 \mathrm{Mcal} / \mathrm{kg}$ of $\mathrm{DM}, \mathrm{n}=5$.

downregulated in blood PMN from OVE- or CON-fed cows. Genes that differed at a given time point (i.e., 0 or $12 \mathrm{~h}$ ) between OVE- and CON-fed cows are shown in Figure 1. At $0 \mathrm{~h}$, the expression of $S 100 A 9$ was upregulated (2.5-fold) for OVE- rather than CON-fed cows. By $12 \mathrm{~h}$ post-LPS challenge, OVE resulted in an upregulation of NFKB1 (1.5-fold), TLR2 (1.8-fold), and HIF1A (1.9-fold).

Supplemental Table 5 reports the LSM and SEM for the effect of IM LPS challenge on gene expression in blood PMN. Regardless of prepartal diet, postpartal IM LPS challenge resulted in an upregulation of genes associated with the inflammatory response (i.e., $A L$ OX5AP, BPI, CYBB, ITGAM, NFKB1, SELL, SOD2, STAT3, S100A8, S100A9, TLN1, TLR2, and VCL), metabolism (i.e., $L D H A$ and PLA2G4A), and transcription (i.e., PPARD and NCOR1). Intramammary LPS challenge resulted in a downregulation of several genes associated with the inflammatory response (i.e., $I L 1 B$, ITGA4, LTA 4H, LYZ, and MPO), metabolism (i.e., $S L$ C2A1), and transcription (e.g., PPARA, PPARG, and NCOR2). The effect of IM LPS challenge on the relative expression for genes associated with metabolism and transcription, including SLC2A1, LDHA, PPARA, $P P A R D, P P A R G$ and $R X R A$, are shown in Figure 2. Regardless of prepartal diet, IM LPS challenge resulted in a downregulation of SLC2A1 (-1.8-fold change), PPARA (-2.4-fold), and PPARG (-2.0-fold), whereas $L D H A$ (1.8-fold) and PPARD (1.7-fold) were upregulated.

\section{Carryover Effect of Prepartal Diet During the Postpartal Period}

No differences in daily DMI and milk yield were observed between OVE and CON cows during the 

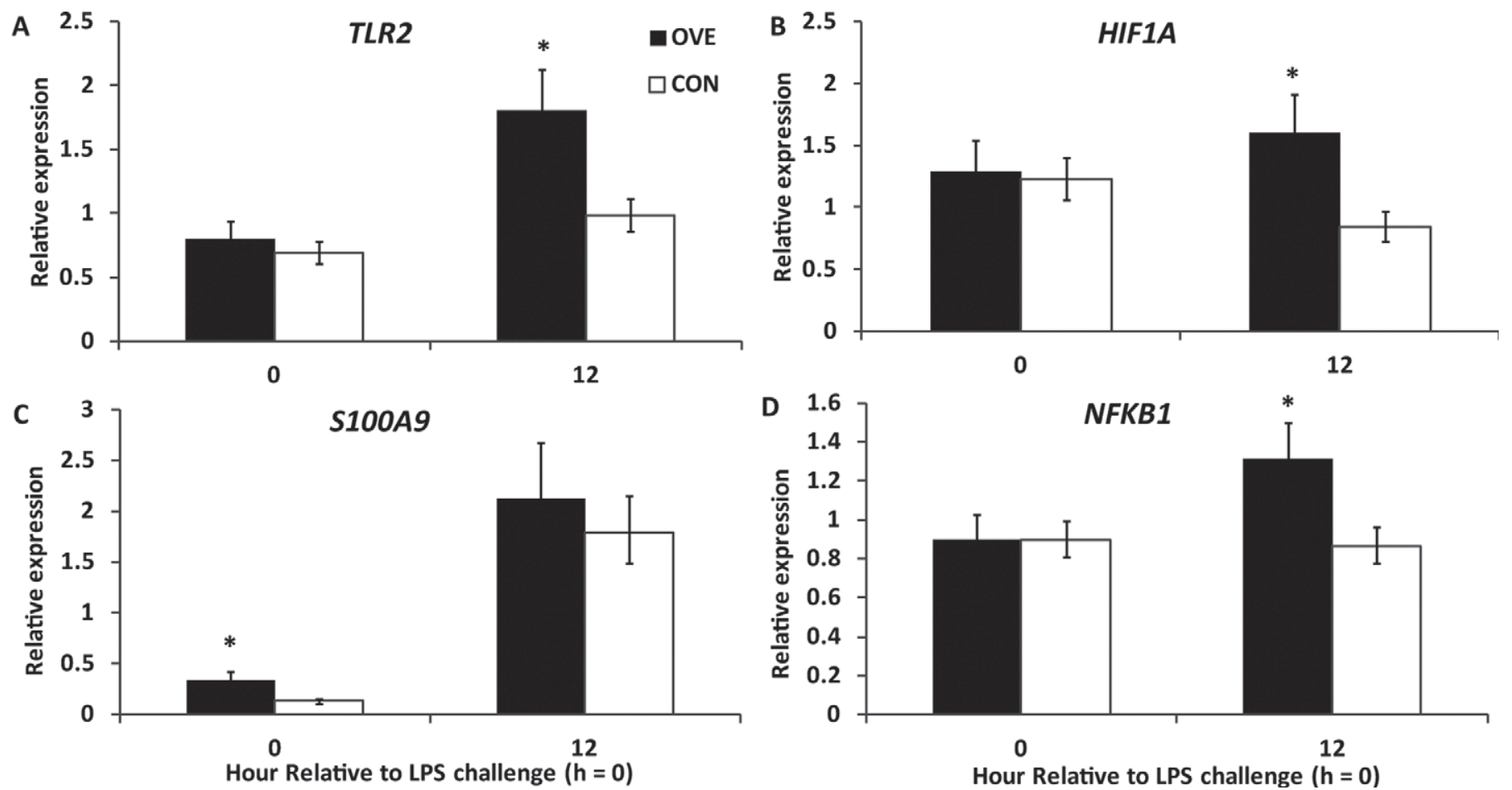

Figure 1. Quantitative real-time PCR gene expression for TLR2 (A), HIF1A (B), S100A9 (C), and NFKB1 (D) in blood neutrophils isolated 0 and $12 \mathrm{~h}$ after intramammary challenge with LPS from dairy cows at 7 DIM fed either control $(\mathrm{CON} ; 1.34 \mathrm{Mcal} / \mathrm{kg}$ of DM, $\mathrm{n}=8)$ or excess energy (OVE; $1.62 \mathrm{Mcal} / \mathrm{kg}$ of DM, $\mathrm{n}=5)$ during the dry period. An asterisk $\left(^{*}\right)$ indicates genes that differed $(P<0.05)$ at any given time point.

postpartal period (Supplemental Figure 1). At 14 DIM, PMN phagocytosis was lower for OVE- than CON-fed cows (Figure 3). Over-feeding energy during the dry period downregulated the transcription of ALOX5 (-1.2fold) and LSP1 (-1.3-fold), regardless of DIM (Table 2 ). Figure 4 shows the effect of diet on blood PMN gene expression throughout the first 30 DIM. No differences were observed between OVE- and CON-fed cows at any time point during the postpartal period for $I L 1 B, I L 8$, $L Y Z, S 100 A 8, H I F 1 A, L D H A$, and PPARG. At 7 DIM, an upregulation of $S 100 A 9$ tended $(2.2$-fold; $P<0.10$ ) to be observed for OVE- rather than CON-fed cows and no other gene expression differences were observed between OVE- and CON-fed cows at 7 DIM. At 14 DIM, OVE-fed cows showed an upregulation of NCOR2 (1.6-fold) and $R X R A$ (1.9-fold) and, at 30 DIM, an upregulation of $M P O$ (3.5-fold) and PLA2G4A (1.5-fold), and a tendency for $R X R A$ (1.7-fold) compared with CON-fed cows.

The majority of genes relating to inflammation, metabolism, and transcription were altered by DIM, regardless of prepartal diet, and are shown in Supplemental Figure 2. As DIM increased, an upregulation of $L Y Z, M P O, T N F, P P A R G$, and SLC2A1 was observed, whereas only $S 100 A 8$ was downregulated as lactation progressed (Table 2). At 14 DIM, transcriptional ex- pression was upregulated for $G 6 P D, S E L L, S T A T 3$, $I L 1 B, I L 8, N C O R 2$, and $R X R A$ when compared with 7 and 30 DIM.

\section{DISCUSSION}

\section{Effect of IM LPS Challenge}

Regardless of prepartal diet, IM LPS challenge resulted in an upregulation of genes in blood PMN primarily associated with the proinflammatory response (NFKB1, STAT3, S100A8, and S100A9), immune activation (TLR2), leukotriene synthesis (ALOX5AP), PMN adhesion or migration (SELL, TLN1, and VCL), and respiratory burst (SOD2). Intramammary LPS challenge also altered the expression of genes associated with metabolism and represents the first characterization of transcription-level changes in bovine blood PMN during early lactation after inflammatory challenge in vivo.

During the peripartal period, glucose availability is low and glucose is a major metabolic fuel used by phagocytes during inflammation (Ingvartsen and Moyes, 2013). Glucose uptake in PMN is facilitated via the insulin-independent glucose transporter-1 (GLUT-1), which is responsible for the low level of basal glucose 
A

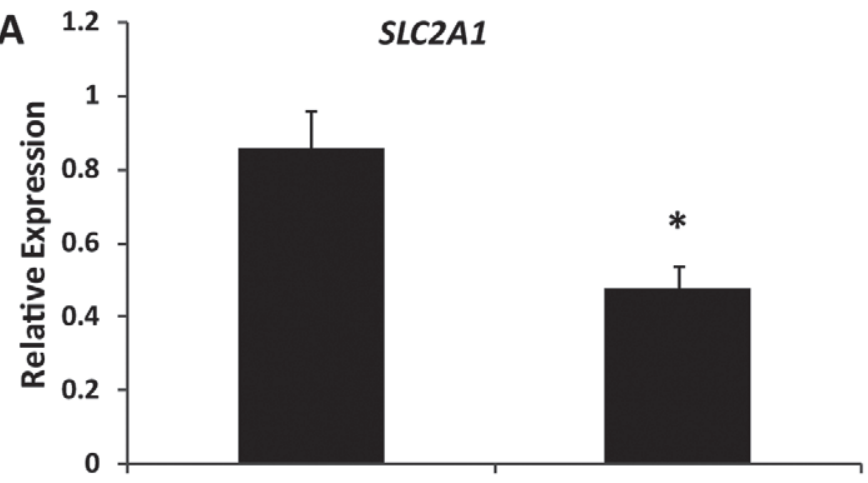

0

C

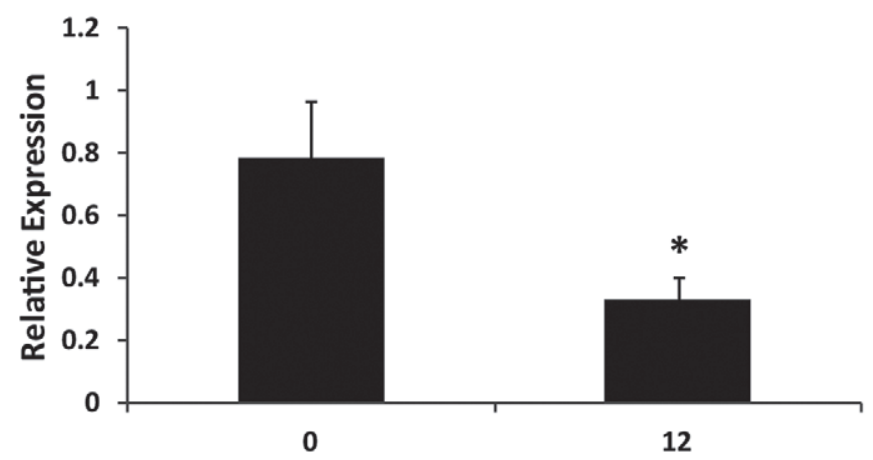

E

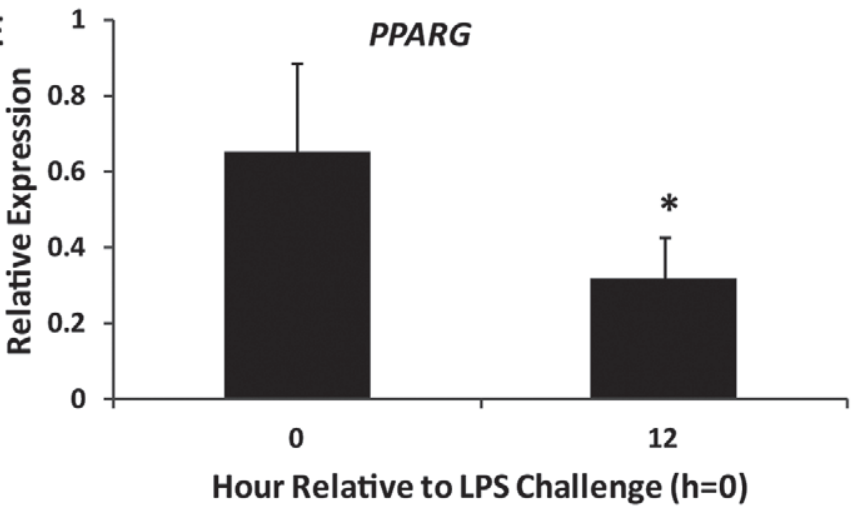

B

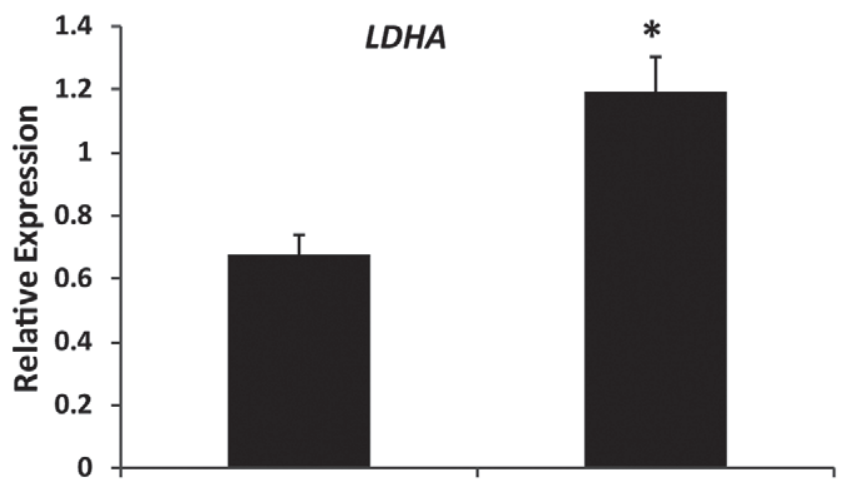

0

D

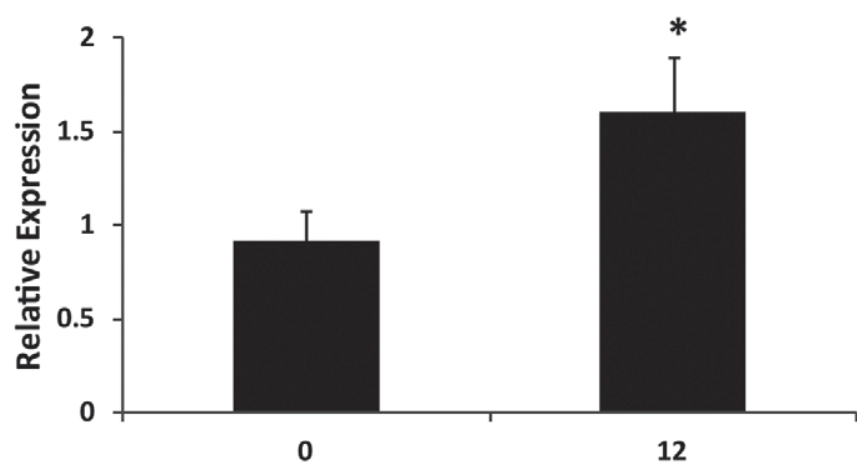

F

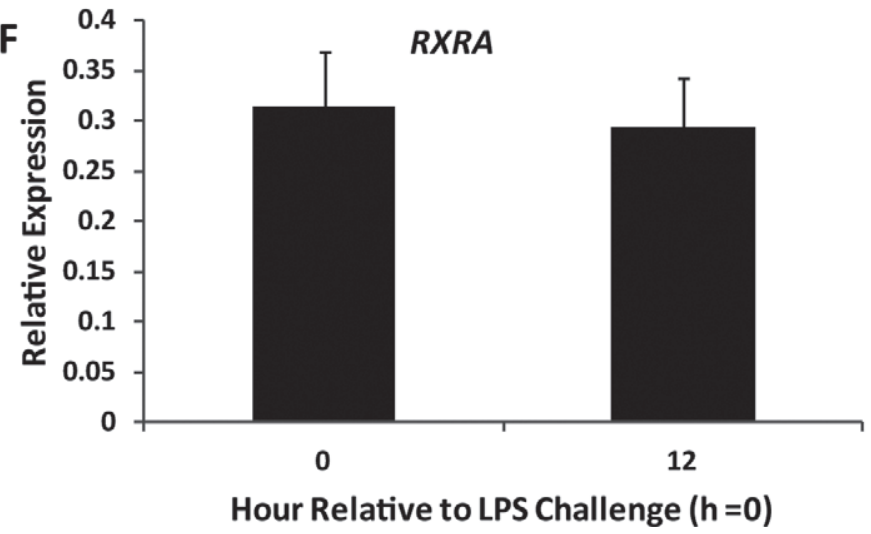

Figure 2. Quantitative real-time PCR gene expression for SLC2A1 (A), LDHA (B), PPARA (C), PPARD (D), PPARG (E), and RXRA $(\mathrm{F})$ in blood neutrophils isolated 0 and $12 \mathrm{~h}$ after intramammary challenge with LPS from dairy cows at 7 DIM. An asterisk $(*)$ indicates genes that differed $(P<0.05)$ between 0 and $12 \mathrm{~h}$.

uptake by phagocytes (Schuster et al., 2007; Ingvartsen and Moyes, 2013), and is required for the ingestion of invading microorganisms (Barghouthi et al., 1995). Interestingly, we observed a downregulation of SLC2A1, the gene coding for GLUT-1, whereas blood glucose concentrations remained unchanged after IM LPS challenge (Graugnard et al., 2013). The results of Schuster et al. (2007) suggest that the translocation, not surface expression of GLUT-1, mediates the uptake of glucose by murine PMN after LPS challenge in vitro. However, Fukuzumi et al. (1996) observed an increase in the amount of GLUT-1 mRNA after LPS stimulation of murine macrophages in vitro. Little is known regarding the mechanisms that control glucose regulation in bovine blood PMN after an inflammatory response. The downregulation of SLC2A1 after IM LPS challenge may also be associated with a potential increase in the number of immature PMN. Intramammary LPS cause a dramatic inflammatory response and release of immature PMN from the bone marrow into circulation. Paape et al. (2003) found that before an IM LPS challenge, circulating PMN consisted of 98\% mature-segmented 


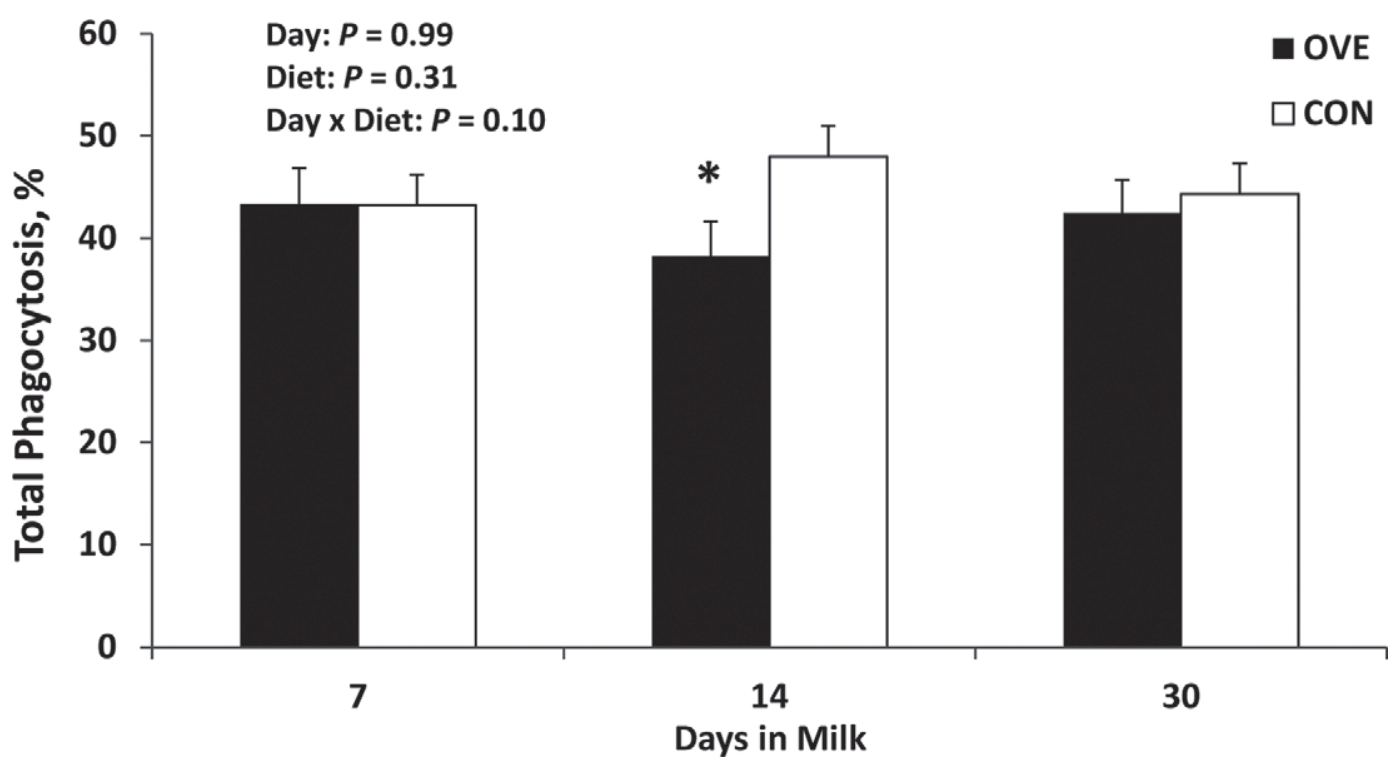

Figure 3. Differences $\left[P<0.05\right.$; denoted by an asterisk $\left.\left(^{*}\right)\right]$ in the percentage of engulfment of fluorescent beads by bovine blood neutrophils as a measure of phagocytosis at 7, 14, and 30 DIM for dairy cows fed either control (CON; $1.34 \mathrm{Mcal} / \mathrm{kg}$ of DM, n = 8) or excess energy (OVE; $1.62 \mathrm{Mcal} / \mathrm{kg}$ of $\mathrm{DM}, \mathrm{n}=5$ ) during the dry period.

cells and $2 \%$ banded cells. However, at $18 \mathrm{~h}$ post-IM LPS infusion, a left shift in the blood PMN population occurs, resulting in mature-segmented PMN accounting for only $43 \%$ of the total and immature-banded cells and juvenile myelocytes or metamyelocytes accounting for 22 and $35 \%$, respectively. Immature PMN have reduced immune function when compared with mature PMN (Paape et al., 2003), but differences in glucose regulation are currently unknown. Although PMN morphology was not assessed in this study, future studies are needed to examine whether changes in PMN glucose metabolism during inflammation are a result of reduced function of immature compared with mature PMN. Such knowledge may lead to new strategies to enhance PMN function and improve cow health during the periparturient period.

Intramammary LPS challenge increased the expression of $L D H A$, which is involved in the interconversion of pyruvate to lactate during glycolysis (Ganapathy et al., 2009). No differences in the expression of $L D H A$ were observed between the OVE and CON groups during IM LPS challenge. Expression of G6PD was not altered by IM LPS challenge and suggests that the conversion of glucose to glucose-6-phosphate (i.e., the first step in glycolysis) remained unchanged. This is supported by the downregulation of SLC2A1 after IM LPS challenge. Metabolic changes that occur in bovine PMN during inflammation are complex and remain largely uncharacterized. Studies of fuel use by activated murine macrophages utilizing ${ }^{14} \mathrm{C}$-labeled glucose indicated that only $5 \%$ of glucose is completely oxidized via the Krebs cycle, with the remainder primarily converted to lactate (Newsholme et al., 1987). The upregulation of $L D H A$ suggests a potential increase in conversion of pyruvate to lactate in bovine PMN during an inflammatory response. Such a response would agree with observations in murine macrophages (Newsholme et al., 1986, 1987). The effect of physiological state and stage of lactation on the metabolic and inflammatory response of PMN in dairy cows may provide new linkages between metabolic status and risk of infectious disease during early lactation.

Peroxisome proliferator-activated receptors- $\alpha,-\delta$, and $-\gamma$ are ligand-activated transcription factors and members of a nuclear receptor family highly expressed in liver and adipose tissues (i.e., PPAR- $\alpha$ and PPAR- $\gamma$; Rosenson et al., 2012) and immune cells (i.e., PPAR- $\gamma$; Lee and Evans, 2002). To our knowledge, we are the first to report the effect of IM LPS challenge on the expression of PPARA, PPARD, and PPARG in blood $\mathrm{PMN}$ of periparturient cows. In one of our previous studies, however, we reported the first evidence suggesting that hepatic PPARD (despite its much lower abundance compared with PPARA; Bionaz et al., 2013) is involved in the inflammatory response (Graugnard et al., 2013). Liver from cows receiving an IM LPS challenge at 7 DIM, regardless of prepartal level of dietary energy, had a marked upregulation of PPARD at $\sim 2 \mathrm{~h}$ postchallenge, whereas expression of PPARA was downregulated. In the present study, no differences for PPAR were observed between the CON and OVE groups at any time point. 
Table 2. Quantitative real-time PCR gene expression of blood neutrophils isolated from dairy cows at 7, 14 , and 30 DIM fed either control ${ }^{1}$ $(\mathrm{CON})$ or excess energy (OVE) during the dry period

\begin{tabular}{|c|c|c|c|c|}
\hline \multirow[b]{2}{*}{ Gene symbol } & & \multicolumn{3}{|c|}{$P$-value } \\
\hline & & Day & Diet & Day $\times$ diet \\
\hline \multicolumn{5}{|l|}{ Inflammation } \\
\hline$A L O X 5$ & Arachidonate 5-lipoxygenase & $<0.001$ & 0.005 & 0.18 \\
\hline$A L O X 5 A P$ & Arachidonate 5 -lipoxygenase-activating protein & $<0.001$ & 0.65 & 0.58 \\
\hline$B P I$ & Bactericidal/permeability-increasing protein & 0.04 & 0.70 & 0.25 \\
\hline$C Y B B$ & Cytochrome $b-245, \beta$ polypeptide & 0.04 & 0.65 & 0.62 \\
\hline ITGA4 & Integrin, $\alpha 4$ & $<0.001$ & 0.72 & 0.06 \\
\hline ITGAM & Integrin, $\alpha \mathrm{M}$ & 0.003 & 0.61 & 0.14 \\
\hline ITGB2 & Integrin, $\beta 2$ & 0.51 & 0.34 & 0.06 \\
\hline LSP1 & Lymphocyte-specific protein & 0.61 & 0.03 & 0.31 \\
\hline LTA4H & Leukotriene A4 hydrolase & 0.02 & 0.27 & 0.20 \\
\hline$L Y Z$ & Lysozyme & $<0.001$ & 0.34 & $<0.001$ \\
\hline$M P O$ & Myeloperoxidase & $<0.001$ & 0.13 & 0.05 \\
\hline S100A9 & S100 calcium-binding protein A9 & 0.001 & 0.48 & $<0.001$ \\
\hline$T L N 1$ & Talin-1 & 0.02 & 0.72 & 0.42 \\
\hline TLR2 & Toll-like receptor 2 & 0.18 & 0.79 & 0.19 \\
\hline$T N F$ & Tumor necrosis factor & $<0.001$ & 0.57 & 0.14 \\
\hline$V C L$ & Vinculin & 0.005 & 0.31 & 0.34 \\
\hline \multicolumn{5}{|c|}{ Metabolism or transcription } \\
\hline$G 6 P D$ & Glucose-6-phosphate dehydrogenase & $<0.001$ & 0.47 & 0.39 \\
\hline HIF1A & Hypoxia-inducible factor, $\alpha$ & 0.02 & 0.59 & 0.007 \\
\hline LDHA & Lactate dehydrogenase, $\alpha$ & 0.08 & 0.82 & 0.007 \\
\hline NCOR 1 & Nuclear receptor corepressor 1 & 0.08 & 0.62 & 0.15 \\
\hline NCOR2 & Nuclear receptor corepressor 2 & 0.001 & 0.16 & $<0.001$ \\
\hline$P L A 2 G 4 A$ & Phospholipase A2, group IVA & 0.08 & 0.17 & 0.01 \\
\hline PPARA & Peroxisome proliferator-activated receptor, $\alpha$ & 0.009 & 0.60 & 0.12 \\
\hline PPARD & Peroxisome proliferator-activated receptor, $\delta$ & $<0.001$ & 0.81 & 0.70 \\
\hline
\end{tabular}

${ }^{1} \mathrm{CON}=1.34 \mathrm{Mcal} / \mathrm{kg}$ of DM, $\mathrm{n}=8 ; \mathrm{OVE}=1.62 \mathrm{Mcal} / \mathrm{kg}$ of DM, $\mathrm{n}=5$.

Although PPAR- $\gamma$ is proposed to be involved in lipid metabolism of macrophages (Lee and Evans, 2002) during inflammation, it is unlikely that the downregulation we observed is physiologically relevant in bovine PMN because of its very low abundance compared with $P P A$ $R A$ and PPARD (Bionaz et al., 2013). If its function in $\mathrm{PMN}$ is similar to liver, the downregulation of PPARA may indicate a decrease in FA oxidation for energy. However, the upregulation of PPARD would not only enhance FA oxidation for generating energy during inflammation but also serve as part of the inflammatory response as has been shown previously in vitro (Ding et al., 2006). For instance, upregulation of PPARD might serve to control the proinflammatory response of PMN by preventing marked upregulation of proinflammatory cytokines, such as TNF (Ding et al., 2006). Little is known regarding FA oxidation by phagocytes, especially during the inflammatory response. Previous studies have characterized the metabolism of oleate by resting murine macrophages and have shown that longchain FA might provide acetyl-CoA as a substrate for the citric acid cycle, thus, serving as a primary fuel for immune cells (Newsholme and Newsholme, 1989). However, the metabolism and fate of long-chain FA by bovine PMN during an inflammatory challenge and how this response differs by stage of lactation is currently unknown. Future studies examining how alterations in PPAR expression relate to bovine PMN FA oxidation during infection at different stages of lactation are warranted.

Prepartal diet had minimal effects at 7 DIM on genes associated with the inflammatory response during IM LPS challenge. Expression of HIF1A was not altered by IM LPS challenge, whereas HIF1A expression was upregulated in OVE rather than CON cows at $12 \mathrm{~h}$ postIM LPS challenge. In leukocytes, HIF1A plays a central role in glycolysis, ATP availability, and bactericidal capacity (Cramer and Johnson, 2003; Peyssonnaux et 

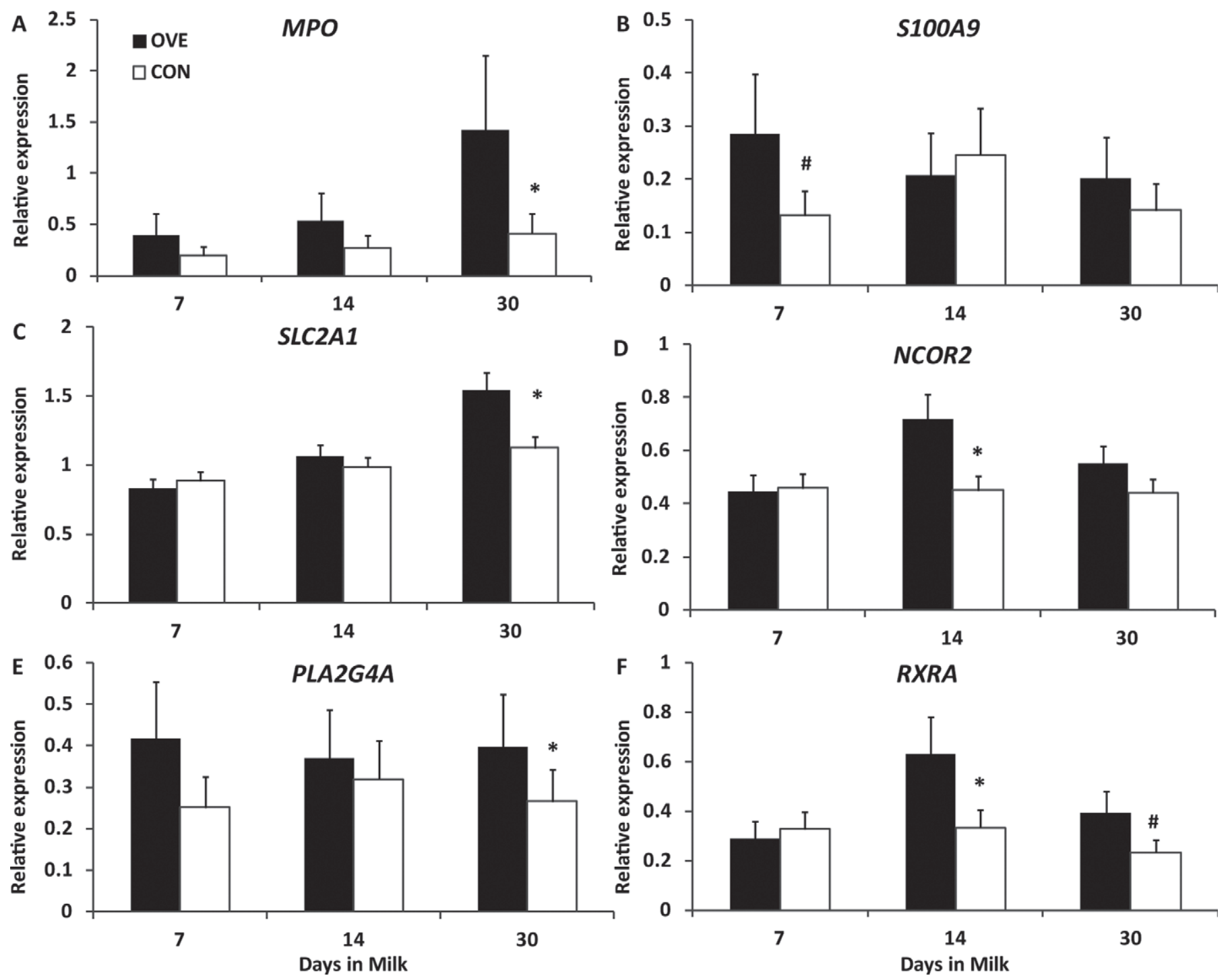

Figure 4. Quantitative real-time PCR gene expression for MPO (A), S100A9 (B), SLC2A1 (C), NCOR2 (D), PLA2G4A (E), and RXRA (F) in blood neutrophils isolated at 7, 14, and 30 DIM from dairy cows fed either control (CON; $1.34 \mathrm{Mcal} / \mathrm{kg}$ of DM, n = 8) or excess energy (OVE; $1.62 \mathrm{Mcal} / \mathrm{kg}$ of $\mathrm{DM}, \mathrm{n}=5)$ during the dry period. An asterisk $\left(^{*}\right)$ indicates genes that differed $(P<0.05)$ at any given time point; a hashmark $(\#)$ indicates genes that differed $(P<0.10)$ at any given time point.

al., 2005). Recent evidence suggests that rapamycin regulates neutrophil extracellular traps (NET) formation by posttranscriptional control of the expression of HIF1A (McInturff et al., 2012). The regulation of NET formation in bovine PMN, especially during early lactation, is largely unknown. Our results may help identify new mechanisms that control NET formation and how prepartal plane of nutrition increases risk of infectious disease during early lactation.

At $0 \mathrm{~h}, S 100 \mathrm{~A} 9$ expression was higher in OVE than CON cows (2.6-fold). During the prepartal period, OVE cows had a higher BCS and positive energy balance than CON cows with greater plasma NEFA and liver triacylglycerol content postpartum (Graugnard et al., 2013). Both S100A8 and S100A9, calcium-binding proteins, are involved in the control of oxidative metabolism of PMN (Bréchard et al., 2013), activation of both p38 mitogen-activated protein kinase (MAPK), NF- $\kappa$ B signaling (Kwon et al., 2013), and the autocrine or paracrine regulatory mechanisms underlying the inflammatory process (Ehrchen et al., 2009). In addition, our results seem to support recent evidence suggesting a role of S100A9 in insulin resistance where both S100A8 and S100A9 in peripheral blood were positively correlated with visceral fat adiposity in obese patients (Yamaoka et al., 2013).

Toll-like receptors are also associated with the activation of the NF- $\kappa \mathrm{B}$ proinflammatory pathway that 
ultimately activates the transcription of inflammatory cytokines such as TNF- $\alpha$, IL1- $\beta$, and IL-10. At $12 \mathrm{~h}$ postLPS challenge, both TLR2 and NFKB1 were upregulated in OVE- rather than CON-fed cows. The expression of NFKB1 is associated with the proinflammatory response, such as the production of cytokines (i.e., TNF, IL-1 $\beta$, and IL-8) and TLR-signaling (Moyes et al., 2009a). We have previously shown that TLR2 and TLR4 were upregulated in blood PMN at $24 \mathrm{~h}$ post-IM challenge with Streptococcus uberis in cows subjected to dietary-induced negative energy balance when compared with cows fed ad libitum during midlactation (Moyes et al., 2010). Cows in negative energy balance had higher plasma NEFA before IM challenge. In a companion study, we reported that, during the postpartal period, OVE cows experienced lower calculated negative energy balance as well as higher plasma NEFA and liver triacylglycerol content than CON-fed cows (Graugnard et al., 2013). Adipocyte lipolysis that occurs during early lactation results in plasma NEFA enriched with SFA (i.e., palmitic and stearic acid; Douglas et al., 2007) and is proposed to be the primary source of elevated NEFA in blood during inflammation (Zu et al., 2009). Palmitic acid is a major component of the lipid A (TLR-4 agonist) portion of LPS (Lee and Hwang, 2006). Our results support the growing evidence suggesting that SFA activate TLR-2 and that SFA may act as ligands for TLR. However, the relationship between the rate and extent of adipose tissue mobilization and TLR signaling is poorly understood and warrants further investigation. The expression of TLR 4 was deemed undetectable because the median cycle threshold in the present study was $>30$. Matsuguchi et al. (2000) reported that TLR2, but not TLR4, was upregulated in mouse splenic macrophages in response to LPS challenge in vitro, suggesting that perhaps TLR-4 is the dominant receptor for at least some types of LPS.

To our knowledge, we are the first to characterize the immunometabolic response of genes in blood PMN during LPS challenge in early lactation cows. Furthermore, this represents the first characterization of how the transcriptional response differs based on prepartal dietary energy intake. Results identified new linkages between immune and metabolic responses of PMN and provide new avenues for future research examining posttranscriptional changes in PMN and risk of mastitis during early lactation.

\section{Carryover Effect of Prepartal Diet During the Postpartal Period}

Overall, we observed an increase in the expression of genes associated with the metabolic and inflammatory response at 14 and 30 DIM when compared with
7 DIM. The natural immunosuppression normally observed around parturition is characterized by decreased function of PMN, such as lower production of reactive oxygen species, migratory capacity, and expression of adhesion molecules (Weber et al., 2001; Hammon et al., 2009). The causative factors for impaired PMN function, specifically respiratory burst activity, during early lactation have not been fully elucidated. Revelo and Waldron (2010) observed a decrease in reactive oxygen species production and extracellular $\mathrm{O}_{2}{ }^{-}$production in blood PMN from cows in early lactation (i.e., 7 DIM) when compared with prepartal cows (i.e., $-12 \mathrm{~d}$ before parturition) and cows in midlactation (i.e., $235 \pm 25$ DIM). Stevens et al. (2011) reported a downregulation of genes associated with TLR-4 signaling (i.e., TRAF6, $A T F 3, I L 8$, and $C 5 a R$ ) in blood PMN for cows in early (3 DIM) when compared with midlactation (i.e., 150 DIM) with no differences observed with regard to TLR4 expression between early and midlactation groups. Previously, we observed a decrease in PMN chemotaxis in vitro in response to IL-8 at 7 DIM when compared with -14 d before ECD (Graugnard et al., 2012). Few studies have characterized the changes in gene expression of bovine blood PMN throughout early lactation. For this study, we did not determine how this response differs when compared with cows at different physiological states or stage of lactation, which warrants further investigation.

Compared with CON, OVE-fed cows had lower PMN phagocytic capabilities postpartum (i.e., 14 DIM), which supports the lower PMN phagocytosis observed for OVE- rather than CON-fed cows during the prepartal period (Graugnard et al., 2012). Previous research has shown that negative energy balance (Moyes et al., 2009b) and the metabolites that characterize the degree of negative energy balance (Klucinski et al., 1988; Calder et al., 1990; Ingvartsen and Moyes, 2013) impair PMN phagocytosis. By design, DMI for OVE-fed cows exceeded energy requirements during the prepartum period, resulting in more negative energy balance during wk 1 after calving than CON-fed cows (Graugnard et al., 2012) and may partly explain the lower PMN phagocytosis for OVE-fed cows.

In contrast, over-feeding energy during the dry period resulted in an upregulation of genes associated with inflammation (e.g., S100A9 and MPO), metabolism (e.g., PLA2GA4 and SLC2A1), and transcription (e.g., NCOR2 and $R X R A$ ) when compared with CONfed cows postpartum. Myeloperoxidase is the enzyme encoded by $M P O$ and is involved in PMN respiratory burst and has been associated with neutrophil extracellular traps-mediated microbial killing (Parker and Winterbourn, 2012). This enzyme catalyzes the formation of hypochlorous acid, a major weapon used 
by phagocytes to kill ingested microorganisms, from $\mathrm{H}_{2} \mathrm{O}_{2}$. As previously stated, $\mathrm{S} 1009 \mathrm{~A}$ is a $\mathrm{Ca}^{2+}$-binding protein that is phagocyte-specific (Bréchard et al., 2013). Both MPO and S100A9 proteins are involved in NADPH oxidase activity, which converts superoxide anion radials to $\mathrm{H}_{2} \mathrm{O}_{2}$. The upregulation of both $M P O$ and $S 100 A 9$ postpartum contradicts the lower in vitro PMN phagocytosis observed for OVE- compared with CON-fed cows. However, MPO and S100A9 expression was not different between OVE- and CON-fed cows at 14 DIM (i.e., when phagocytosis was lower in OVE-fed cows). It is likely that the expression of genes may not reflect posttranslational expression of these proteins at 14 DIM.

The regulation of NADPH oxidase is not fully understood, and S100A8 and S100A9 proteins have been proposed as essential regulators of NADPH oxidase activation (Bréchard et al., 2013). Studies suggest that NADPH oxidase activity is $\mathrm{Ca}^{2+}$-dependent and is potentially mediated via a S100A8 and S100A9 translocation to the membrane, thereby activating NADPH oxidase during phagocytosis (Schenten et al., 2010, 2011). Furthermore, PLA2GA4 encodes the cytosolic phospholipase A2 enzyme, which is activated by increased intracellular $\mathrm{Ca}^{2+}$, and hydrolyzes phospholipids to release arachidonic acid, which is involved in the production of proinflammatory eicosanoids (Funk, 2001) . This cytosolic phospholipase A2 generation of arachidonic acid has been shown to be essential for the activation of NADPH oxidase (Dana et al., 1998; Pessach et al., 2001), although this complex interaction has not been fully elucidated. Whether a change in the mRNA expression of S100A9 and PLA2GA4 of PMN translates to changes at the level of protein expression is unknown.

Over-feeding energy during the dry period resulted in an upregulation of SLC2A1 at 30 DIM in OVE- rather than CON-fed cows. No differences were observed for blood glucose or insulin concentration by 21 DIM between OVE- and CON-fed cows (Graugnard et al., 2013). Regardless of diet, the expression of SLC2A1 increased as DIM progressed. An upregulation of GLUT1 in bovine mammary tissue during early lactation when compared with later lactation has been previously reported (Mattmiller et al., 2011). Whether glucose uptake increases in bovine blood PMN as lactation progresses and the linkages between glucose uptake and metabolic status are currently unknown and warrant further investigation.

Although the expression of PPAR was not altered by diet at any given time point during early lactation, expression of $R X R A$ was upregulated in OVEwhen compared with CON-fed cows at both 14 and 30 DIM, and NCOR2 was also upregulated in OVE at
14 DIM. The retinoid X receptor transcriptional complex, regulated via PPAR signaling, is associated with lipid metabolism and inflammation (Rosenson et al., 2012). The nuclear receptor corepressor 2 represses the target-gene expression action of PPAR via binding to nonliganded PPAR (Hsia et al., 2010). Of the 3 PPAR studied, only PPARD was upregulated at 14 DIM, regardless of diet (Supplemental Figure 1). Therefore, it could be possible that, in blood PMN of cows fed OVE, the upregulation of $R X R A$ was a response to counteract the inhibitory effect of NCOR2. Despite the fact PPAR have AA residues that could be phosphorylated via MAPK and protein kinase signaling (Diradourian et al., 2005; Burns and Vanden Heuvel, 2007), it is well established that physiological regulation of PPAR signaling occurs primarily as a result of ligand availability (and recruitment of coactivators; Ricote and Glass, 2007; Yu and Reddy, 2007) rather than posttranscriptional or posttranslational modifications. It remains to be determined, however, if the mRNA expression of PPAR during inflammation in dairy cattle is accompanied by similar changes in protein expression.

Recent in vitro work using whole bovine blood provided evidence that activation of $\operatorname{PPAR}-\gamma$ via a chemical ligand (rosiglitazone) reduced the concentration of TNF- $\alpha$ when LPS was added to culture medium (Perdomo et al., 2011). Among linoleic acid, cis9, trans11-18:2, and trans10,cis12-18:2, only the latter had a similar effect on TNF- $\alpha$ concentration; thus, this evidence suggests that PPAR signaling in immune cells is physiologically relevant. Further studies with agonists and antagonists of PPAR- $\alpha$ and PPAR- $\delta$ seem warranted to determine their relevance in the context of PMN function.

\section{CONCLUSIONS}

Little is known regarding the immune-metabolic response of genes in bovine blood PMN during inflammation and whether prepartal energy intake influences PMN function postpartum. To the best of our knowledge, our study is the first to characterize the expression of genes associated with metabolism in PMN after IM PLS challenge. We observed that glucose uptake and metabolism and lipid oxidation are altered at the transcription level during IM LPS challenge. Overfeeding energy during the dry period upregulated the expression of genes associated with the immune response. We have shown that over-feeding energy during the dry period decreases PMN phagocytosis in vitro and upregulates genes associated with neutrophil extracellular traps formation, oxidative metabolism, and TLR signaling after IM LPS challenge during the early postpartal period. These results provide new avenues 
regarding the linkages among feed energy intake, metabolism, and immune response of bovine blood PMN during early lactation. Future studies examining the relationship between energy status and inflammation are needed to better understand the mechanisms that relating energy balance and risk of infectious disease (i.e., mastitis) during early lactation.

\section{ACKNOWLEDGMENTS}

The authors thank Travis Michels and Mike Katterhenry of the University of Illinois Dairy Research Unit (Urbana) staff for help with animal management, and Mario Ordonez ((dairy processing coordinator, La Pampilla, Ecuador) for help during sampling and data collection. Appreciation also is extended to Massimo Bionaz, Walter Hurley, Janeen Salak-Johnson, Richard L. Wallace, and Dawn Morin (University of Illinois, Urbana) for helpful discussions during development and conduct of the project. M. J. Khan, on leave from COMSATS Institute of Information Technology (CIIT), Islamabad, Pakistan, thanks CIIT for a fellowship to pursue an MS degree at the University of Illinois, Urbana.

\section{REFERENCES}

Bar, D., L. W. Tauer, G. Bennett, R. N. Gonzalez, J. A. Hertl, Y. H. Schukken, H. F. Schulte, F. L. Welcome, and Y. T. Grohn. 2008. The cost of generic clinical mastitis in dairy cows as estimated by using dynamic programming. J. Dairy Sci. 91:2205-2214.

Barghouthi, S., K. D. Everett, and D. P. Speert. 1995. Nonopsonic phagocytosis of Pseudomonas aeruginosa requires facilitated transport of D-glucose by macrophages. J. Immunol. 154:3420-3428.

Bionaz, M., S. Chen, M. J. Khan, and J. J. Loor. 2013. Functional role of PPARs in ruminants: Potential targets for fine-tuning metabolism during growth and lactation. PPAR Res. 2013:684159.

Bionaz, M., and J. J. Loor. 2012. Ruminant metabolic systems biology: Reconstruction and integration of transcriptome dynamics underlying functional responses of tissues to nutrition and physiological state. Gene Regul. Syst. Bio. 6:109-125.

Bréchard, S., S. Plancon, and E. J. Tschirhart. 2013. New insights into the regulation of neutrophil NADPH oxidase activity in the phagosome: A focus on the role of lipid and $\mathrm{Ca}(2+)$ signaling. Antioxid. Redox Signal. 18:661-676.

Burns, K. A., and J. P. Vanden Heuvel. 2007. Modulation of PPAR activity via phosphorylation. Biochim. Biophys. Acta 1771:952-960.

Burvenich, C., E. Monfardini, J. Mehrzad, A. V. Capuco, and M. J. Paape. 2004. Role of neutrophil polymorphonuclear leukocytes during bovine coliform mastitis: Physiology or pathology? Verh. K. Acad. Geneeskd. Belg. 66:97-150.

Calder, P. C., J. A. Bond, and E. A. Newsholme. 1990. Fatty acid inhibition of lipopolysaccharide-stimulated B lymphocyte proliferation. Biochem. Soc. Trans. 18:904-905.

Cramer, T., and R. S. Johnson. 2003. A novel role for the hypoxia inducible transcription factor HIF-1alpha: Critical regulation of inflammatory cell function. Cell Cycle 2:192-193.

Dana, R., T. L. Leto, H. L. Malech, and R. Levy. 1998. Essential requirement of cytosolic phospholipase A2 for activation of the phagocyte NADPH oxidase. J. Biol. Chem. 273:441-445.

Dann, H. M., N. B. Litherland, J. P. Underwood, M. Bionaz, A. D'Angelo, J. W. McFadden, and J. K. Drackley. 2006. Diets during far-off and close-up dry periods affect periparturient metabolism and lactation in multiparous cows. J. Dairy Sci. 89:3563-3577.

Ding, G., L. Cheng, Q. Qin, S. Frontin, and Q. Yang. 2006. PPARdelta modulates lipopolysaccharide-induced TNFalpha inflammation signaling in cultured cardiomyocytes. J. Mol. Cell. Cardiol. 40:821-828.

Diradourian, C., J. Girard, and J. P. Pegorier. 2005. Phosphorylation of PPARs: From molecular characterization to physiological relevance. Biochimie 87:33-38.

Douglas, G. N., J. Rehage, A. D. Beaulieu, A. O. Bahaa, and J. K. Drackley. 2007. Prepartum nutrition alters fatty acid composition in plasma, adipose tissue, and liver lipids of periparturient dairy cows. J. Dairy Sci. 90:2941-2959.

Ehrchen, J. M., C. Sunderkotter, D. Foell, T. Vogl, and J. Roth. 2009. The endogenous Toll-like receptor 4 agonist S100A8/S100A9 (calprotectin) as innate amplifier of infection, autoimmunity, and cancer. J. Leukoc. Biol. 86:557-566.

Fukuzumi, M., H. Shinomiya, Y. Shimizu, K. Ohishi, and S. Utsumi 1996. Endotoxin-induced enhancement of glucose influx into murine peritoneal macrophages via GLUT1. Infect. Immun. 64:108112 .

Funk, C. D. 2001. Prostaglandins and leukotrienes: Advances in eicosanoid biology. Science 294:1871-1875.

Ganapathy, V., M. Thangaraju, and P. D. Prasad. 2009. Nutrient transporters in cancer: Relevance to Warburg hypothesis and beyond. Pharmacol. Ther. 121:29-40.

Graugnard, D. E., M. Bionaz, E. Trevisi, K. M. Moyes, J. L. SalakJohnson, R. L. Wallace, J. K. Drackley, G. Bertoni, and J. J. Loor. 2012. Blood immunometabolic indices and polymorphonuclear neutrophil function in peripartum dairy cows are altered by level of dietary energy prepartum. J. Dairy Sci. 95:1749-1758.

Graugnard, D. E., K. M. Moyes, E. Trevisi, M. J. Khan, D. Keisler, J. K. Drackley, G. Bertoni, and J. J. Loor. 2013. Liver lipid content and inflammometabolic indices in peripartal cows are altered in response to prepartal energy intake and postpartal intramammary inflammatory challenge. J. Dairy Sci. 96:918-935.

Hammon, H. M., G. Sturmer, F. Schneider, A. Tuchscherer, H. Blum, T. Engelhard, A. Genzel, R. Staufenbiel, and W. Kanitz. 2009. Performance and metabolic and endocrine changes with emphasis on glucose metabolism in high-yielding dairy cows with high and low fat content in liver after calving. J. Dairy Sci. 92:1554-1566.

Hoeben, D., C. Burvenich, E. Trevisi, G. Bertoni, J. Hamann, R. M. Bruckmaier, and J. W. Blum. 2000. Role of endotoxin and TNFalpha in the pathogenesis of experimentally induced coliform mastitis in periparturient cows. J. Dairy Res. 67:503-514.

Hsia, E. Y., M. L. Goodson, J. X. Zou, M. L. Privalsky, and H. W. Chen. 2010. Nuclear receptor coregulators as a new paradigm for therapeutic targeting. Adv. Drug Deliv. Rev. 62:1227-1237.

Ingvartsen, K. L., and K. M. Moyes. 2013. Nutrition, immune function and health of dairy cattle. Animal 7(Suppl. 1):112-122.

Janovick, N. A., Y. R. Boisclair, and J. K. Drackley. 2011. Prepartum dietary energy intake affects metabolism and health during the periparturient period in primiparous and multiparous Holstein cows. J. Dairy Sci. 94:1385-1400.

Ji, P., J. S. Osorio, J. K. Drackley, and J. J. Loor. 2012. Overfeeding a moderate energy diet prepartum does not impair bovine subcutaneous adipose tissue insulin signal transduction and induces marked changes in peripartal gene network expression. J. Dairy Sci. 95:4333-4351.

Khan, M. J., A. Hosseini, S. Burrell, S. M. Rocco, J. P. McNamara, and J. J. Loor. 2013. Change in subcutaneous adipose tissue metabolism and gene network expression during the transition period in dairy cows, including differences due to sire genetic merit. J. Dairy Sci. 96:2171-2182.

Klucinski, W., A. Degorski, E. Miernik-Degorska, S. Targowski, and A. Winnicka. 1988. Effect of ketone bodies on the phagocytic activity of bovine milk macrophages and polymorphonuclear leukocytes. Zentralbl. Veterinarmed. A 35:632-639.

Kwon, C. H., H. J. Moon, H. J. Park, J. H. Choi, and Y. Park. 2013. S100A8 and S100A9 promotes invasion and migration through p38 
mitogen-activated protein kinase-dependent NF-kappaB activation in gastric cancer cells. Mol. Cells 35:226-234.

Lacetera, N., D. Scalia, O. Franci, U. Bernabucci, B. Ronchi, and A. Nardone. 2004. Short communication: Effects of nonesterified fatty acids on lymphocyte function in dairy heifers. J. Dairy Sci. $87: 1012-1014$.

Lee, C. H., and R. M. Evans. 2002. Peroxisome proliferator-activated receptor-gamma in macrophage lipid homeostasis. Trends Endocrinol. Metab. 13:331-335.

Lee, J. Y., and D. H. Hwang. 2006. The modulation of inflammatory gene expression by lipids: Mediation through toll-like receptors. Mol. Cells 21:174-185.

Matsuguchi, T., T. Musikacharoen, T. Ogawa, and Y. Yoshikai. 2000. Gene expressions of toll-like receptor 2, but not toll-like receptor 4 , is induced by LPS and inflammatory cytokines in mouse macrophages. J. Immunol. 165:5767-5772.

Mattmiller, S. A., C. M. Corl, J. C. Gandy, J. J. Loor, and L. M. Sordillo. 2011. Glucose transporter and hypoxia-associated gene expression in the mammary gland of transition dairy cattle. J. Dairy Sci. 94:2912-2922.

McInturff, A. M., M. J. Cody, E. A. Elliott, J. W. Glenn, J. W. Rowley, M. T. Rondina, and C. C. Yost. 2012. Mammalian target of rapamycin regulates neutrophil extracellular trap formation via induction of hypoxia-inducible factor 1 alpha. Blood 120:31183125 .

Moyes, K. M., J. K. Drackley, D. E. Morin, M. Bionaz, S. L. Rodriguez-Zas, R. E. Everts, H. A. Lewin, and J. J. Loor. 2009a. Gene network and pathway analysis of bovine mammary tissue challenged with Streptococcus uberis reveals induction of cell proliferation and inhibition of PPARgamma signaling as potential mechanism for the negative relationships between immune response and lipid metabolism. BMC Genomics 10:542.

Moyes, K. M., J. K. Drackley, D. E. Morin, and J. J. Loor. 2010. Greater expression of TLR2, TLR 4, and IL6 due to negative energy balance is associated with lower expression of $H L A-D R A$ and $H L A-A$ in bovine blood neutrophils after intramammary mastitis challenge with Streptococcus uberis. Funct. Integr. Genomics 10:53-61.

Moyes, K. M., J. K. Drackley, J. L. Salak-Johnson, D. E. Morin, J. C. Hope, and J. J. Loor. 2009b. Dietary-induced negative energy balance has minimal effects on innate immunity during a Streptococcus uberis mastitis challenge in dairy cows during midlactation. J. Dairy Sci. 92:4301-4316.

NRC. 2001. Nutrient Requirements of Dairy Cattle. Natl. Acad. Press, Washington, DC.

Newsholme, P., R. Curi, S. Gordon, and E. A. Newsholme. 1986. Metabolism of glucose, glutamine, long-chain fatty acids and ketone bodies by murine macrophages. Biochem. J. 239:121-125.

Newsholme, P., S. Gordon, and E. A. Newsholme. 1987. Rates of utilization and fates of glucose, glutamine, pyruvate, fatty acids and ketone bodies by mouse macrophages. Biochem. J. 242:631-636.

Newsholme, P., and E. A. Newsholme. 1989. Rates of utilization of glucose, glutamine and oleate and formation of end-products by mouse peritoneal macrophages in culture. Biochem. J. 261:211218.

Paape, M. J., D. D. Bannerman, X. Zhao, and J. W. Lee. 2003. The bovine neutrophil: Structure and function in blood and milk. Vet. Res. 34:597-627.

Paape, M., J. Mehrzad, X. Zhao, J. C. Detilleux, and C. Burvenich. 2002. Defense of the bovine mammary gland by polymorphonuclear neutrophil leukocytes. J. Mammary Gland Biol. Neoplasia 7:109-121.

Parker, H., and C. C. Winterbourn. 2012. Reactive oxidants and myeloperoxidase and their involvement in neutrophil extracellular traps. Front. Immunol. 3:424.

Perdomo, M. C., J. E. Santos, and L. Badinga. 2011. Trans-10,cis-12 conjugated linoleic acid and the PPAR-gamma agonist rosiglitazone attenuate lipopolysaccharide-induced TNF-alpha production by bovine immune cells. Domest. Anim. Endocrinol. 41:118 125 .
Pessach, I., T. L. Leto, H. L. Malech, and R. Levy. 2001. Essential requirement of cytosolic phospholipase $\mathrm{A}(2)$ for stimulation of NADPH oxidase-associated diaphorase activity in granulocyte-like cells. J. Biol. Chem. 276:33495-33503.

Peyssonnaux, C., V. Datta, T. Cramer, A. Doedens, E. A. Theodorakis, R. L. Gallo, N. Hurtado-Ziola, V. Nizet, and R. S. Johnson. 2005. HIF-1alpha expression regulates the bactericidal capacity of phagocytes. J. Clin. Invest. 115:1806-1815.

Pithon-Curi, T. C., M. P. De Melo, and R. Curi. 2004. Glucose and glutamine utilization by rat lymphocytes, monocytes and neutrophils in culture: A comparative study. Cell Biochem. Funct. $22: 321-326$.

Raetz, C. R., and C. Whitfield. 2002. Lipopolysaccharide endotoxins. Annu. Rev. Biochem. 71:635-700.

Revelo, X. S., and M. R. Waldron. 2010. Effects of in vitro insulin and 2,4-thiazolidinedione on the function of neutrophils harvested from blood of cows in different physiological states. J. Dairy Sci. 93:3990-4005.

Ricote, M., and C. K. Glass. 2007. PPARs and molecular mechanisms of transrepression. Biochim. Biophys. Acta 1771:926-935.

Rosenson, R. S., R. S. Wright, M. Farkouh, and J. Plutzky. 2012. Modulating peroxisome proliferator-activated receptors for therapeutic benefit? Biology, clinical experience, and future prospects. Am. Heart J. 164:672-680.

Scalia, D., N. Lacetera, U. Bernabucci, K. Demeyere, L. Duchateau, and C. Burvenich. 2006. In vitro effects of nonesterified fatty acids on bovine neutrophils oxidative burst and viability. J. Dairy Sci. $89: 147-154$

Schenten, V., S. Brechard, S. Plancon, C. Melchior, J. P. Frippiat, and E. J. Tschirhart. 2010. iPLA ${ }_{2}$, a novel determinant in $\mathrm{Ca}^{2+}$ - and phosphorylation-dependent S100A8/A9 regulated NOX2 activity. Biochim. Biophys. Acta 1803:840-847.

Schenten, V., C. Melchior, N. Steinckwich, E. J. Tschirhart, and S. Brechard. 2011. Sphingosine kinases regulate NOX2 activity via p38 MAPK-dependent translocation of S100A8/A9. J. Leukoc. Biol. 89:587-596.

Schuster, D. P., S. L. Brody, Z. Zhou, M. Bernstein, R. Arch, D. Link, and M. Mueckler. 2007. Regulation of lipopolysaccharide-induced increases in neutrophil glucose uptake. Am. J. Physiol. Lung Cell. Mol. Physiol. 292:L845-L851.

Stevens, M. G., L. J. Peelman, S. B. De, A. Pezeshki, G. R. Van De Walle, L. Duchateau, and C. Burvenich. 2011. Differential gene expression of the toll-like receptor-4 cascade and neutrophil function in early- and mid-lactating dairy cows. J. Dairy Sci. 94:1277-1288

Vandesompele, J., P. K. De, F. Pattyn, B. Poppe, R. N. Van, P. A. De, and F. Speleman. 2002. Accurate normalization of real-time quantitative RT-PCR data by geometric averaging of multiple internal control genes. Genome Biol. 3:RESEARCH0034. http://dx.doi. org/doi:10.1186/gb-2002-3-7-research0034.

Weber, P. S., S. A. Madsen, G. W. Smith, J. J. Ireland, and J. L. Burton. 2001. Pre-translational regulation of neutrophil L-selectin in glucocorticoid-challenged cattle. Vet. Immunol. Immunopathol. 83:213-240.

Wesche, H., W. J. Henzel, W. Shillinglaw, S. Li, and Z. Cao. 1997. MyD88: An adapter that recruits IRAK to the IL-1 receptor complex. Immunity 7:837-847.

Yamaoka, M., N. Maeda, S. Nakamura, T. Mori, K. Inoue, K. Matsuda, R. Sekimoto, S. Kashine, Y. Nakagawa, Y. Tsushima, Y. Fujishima, N. Komura, A. Hirata, H. Nishizawa, Y. Matsuzawa, K. I. Matsubara, T. Funahashi, and I. Shimomura. 2013. Gene expression levels of S100 protein family in blood cells are associated with insulin resistance and inflammation. Biochem. Biophys. Res. Commun. 433:450-455.

Yu, S., and J. K. Reddy. 2007. Transcription coactivators for peroxisome proliferator-activated receptors. Biochim. Biophys. Acta 1771:936-951.

Zu, L., J. He, H. Jiang, C. Xu, S. Pu, and G. Xu. 2009. Bacterial endotoxin stimulates adipose lipolysis via toll-like receptor 4 and extracellular signal-regulated kinase pathway. J. Biol. Chem. 284:5915-5926. 